\section{Cochrane corner: beta-blockers for hypertension}

\author{
Charles S Wiysonge, ${ }^{1}$ Hazel A Bradley, ${ }^{2}$ Jimmy Volmink, ${ }^{3}$ \\ Bongani M Mayosi ${ }^{4,5}$
}

\section{BACKGROUND}

Beta-blockers refer to an assorted group of medications that block the action of endogenous catecholamines on beta-adrenergic receptors. ${ }^{1}$ The $\beta 1$ and $\beta 2$ receptors are the primary beta-adrenergic receptors in the human cardiovascular system. Betablockers differ in their $\beta 1 / \beta 2$-receptor selectivity and vasodilatory properties. Based on this diversity, beta-blockers have been categorised into first, second and third generation. First-generation betablockers, also referred to as non-selective blockers, possess equal affinity for $\beta 1$ and $\beta 2$ receptors. Second-generation (or selective) beta-blockers exercise more affinity for $\beta 1$ than $\beta 2$ receptors. Neither of these traditional beta-blockers has vasodilatory properties, which is an intrinsic characteristic of third-generation beta-blockers. ${ }^{2}$

Beta-blockers have been known to play a role in blood pressure control since 1949. ${ }^{3}$ We summarise the findings of a Cochrane Review we published in 2017 on the comparative effects of beta-blockers as initial treatment for hypertension. ${ }^{4}$ This is an update of a review we first published 10 years ago. ${ }^{5-7}$

\section{Concise methods}

We searched the Cochrane Library, MEDLINE, EMBASE and ClinicalTrials. gov using a comprehensive database-specific search string and checked reference lists of relevant publications, up to June 2016. We selected randomised trials with a duration of at least 12 months, which assessed the effects of beta-blockers as firstline therapy for hypertension, compared with placebo or other antihypertensive drugs. Eligible studies had to report one or more of the following outcomes:

${ }^{1}$ Cochrane South Africa, South African Medical Research Council, Cape Town, South Africa

${ }^{2}$ School of Public Health, University of the Western

Cape, Cape Town, South Africa

${ }^{3}$ Centre for Evidence-Based Health Care, Faculty of

Medicine and Health Sciences, Stellenbosch University,

Cape Town, South Africa

${ }^{4}$ Department of Medicine, University of Cape Town, Cape Town, South Africa

${ }^{5}$ Groote Schuur Hospital, Cape Town, South Africa

Correspondence to Charles S Wiysonge, Cochrane South Africa, South African Medical Research Council, Francie van Zijl Drive, Parow Valley 7501, Cape Town, South Africa; Charles.Wiysonge@mrc.ac.za all-cause mortality, stroke, coronary heart disease, cardiovascular death and cardiovascular events (ie, coronary heart disease, strokes and heart failure). We used standard Cochrane methods to select eligible studies, assess risk of bias, extract and analyse data and assess the certainty of the evidence. $^{7}$

\section{MAIN RESULTS}

Thirteen studies met our inclusion criteria. These studies compared beta-blockers with placebo or no treatment (four studies), diuretics (five studies), calcium-channel

\begin{tabular}{|c|c|c|c|}
\hline Outcomes & Risk ratio $(95 \% \mathrm{Cl})$ & $\begin{array}{l}\text { No of participants (no of } \\
\text { studies) }\end{array}$ & Certainty of the evidence \\
\hline \multicolumn{4}{|c|}{ Beta-blockers versus placebo } \\
\hline All-cause mortality & 0.99 (0.88 to 1.11$)$ & 23613 (4 studies) & $\begin{array}{l}\oplus \oplus \oplus \ominus \\
\text { Moderate* }\end{array}$ \\
\hline Cardiovascular events & 0.88 (0.79 to 0.97 ) & 23613 (4 studies) & $\begin{array}{l}\oplus \oplus \Theta \ominus \\
\text { Low }^{*}+\end{array}$ \\
\hline Stroke & 0.80 (0.66 to 0.96 ) & 23613 (4 studies) & $\begin{array}{l}\oplus \oplus \ominus \ominus \\
\text { Low* }^{*}+\end{array}$ \\
\hline Coronary heart disease & 0.93 (0.81 to 1.07 ) & 23613 (4 studies) & $\begin{array}{l}\oplus \oplus \oplus \ominus \\
\text { Moderate* }\end{array}$ \\
\hline Adverse events & $3.38(0.82$ to 13.95$)$ & 22729 (3 studies) & $\begin{array}{l}\oplus \oplus \ominus \ominus \\
\text { Low }\end{array}$ \\
\hline \multicolumn{4}{|c|}{ Beta-blockers versus diuretics } \\
\hline All-cause mortality & 1.04 (0.91 to 1.19$)$ & 18241 (5 studies) & $\begin{array}{l}\oplus \oplus \oplus \ominus \\
\text { Moderate* }\end{array}$ \\
\hline Cardiovascular events & 1.13 (0.99 to 1.28$)$ & 18135 (4 studies) & $\begin{array}{l}\oplus \oplus \oplus \ominus \\
\text { Moderate* }^{*}\end{array}$ \\
\hline Stroke & 1.17 (0.65 to 2.09$)$ & 18135 (4 studies) & $\begin{array}{l}\oplus \oplus \ominus \ominus \\
\text { Low* }^{*} \neq\end{array}$ \\
\hline Coronary heart disease & 1.12 (0.82 to 1.54$)$ & 18135 (4 studies) & $\begin{array}{l}\oplus \oplus \ominus \ominus \\
\text { Low* }^{*}\end{array}$ \\
\hline Adverse events & $1.69(0.95$ to 3.00$)$ & 11566 (3 studies) & $\begin{array}{l}\oplus \oplus \Theta \Theta \\
\text { Low* }^{*}\end{array}$ \\
\hline \multicolumn{4}{|c|}{ Beta-blockers versus calcium-channel blockers } \\
\hline All-cause mortality & $1.07(1.0$ to 1.14$)$ & 44825 (4 studies) & $\begin{array}{l}\oplus \oplus \oplus \ominus \\
\text { Moderate† }\end{array}$ \\
\hline Cardiovascular events & 1.18 (1.08 to 1.29$)$ & 19915 (2 studies) & $\begin{array}{l}\oplus \oplus \oplus \Theta \\
\text { Moderate§ }\end{array}$ \\
\hline Stroke & $1.24(1.11$ to 1.4$)$ & 44167 (3 studies) & $\begin{array}{l}\oplus \oplus \oplus \ominus \\
\text { Moderate§ }\end{array}$ \\
\hline Coronary heart disease & 1.05 (0.96 to 1.15$)$ & 44167 (3 studies) & $\begin{array}{l}\oplus \oplus \oplus \ominus \\
\text { Moderate§ }\end{array}$ \\
\hline Adverse events & 1.20 (0.71 to 2.04 ) & 21591 (2 studies) & $\begin{array}{l}\oplus \oplus \Theta \Theta \\
\text { Lowł§ }\end{array}$ \\
\hline \multicolumn{4}{|c|}{ Beta-blockers versus renin-angiotensin system inhibitors } \\
\hline All-cause mortality & 1.10 (0.98 to 1.24$)$ & 10828 (3 studies) & $\begin{array}{l}\oplus \oplus \oplus \ominus \\
\text { Moderate§ }\end{array}$ \\
\hline Cardiovascular events & $1.0(0.72$ to 1.38$)$ & 10828 (3 studies) & $\begin{array}{l}\oplus \oplus \Theta \Theta \\
\text { Low } \neq \S\end{array}$ \\
\hline Stroke & 1.30 (1.11 to 1.53$)$ & 9951 (2 studies) & $\begin{array}{l}\oplus \oplus \oplus \ominus \\
\text { Moderate§ }\end{array}$ \\
\hline Coronary heart disease & 0.90 (0.76 to 1.06$)$ & 9951 (2 studies) & $\begin{array}{l}\oplus \oplus \Theta \ominus \\
\text { Low§ף }\end{array}$ \\
\hline Adverse events & 1.41 (1.29 to 1.54$)$ & 9951 (2 studies) & $\begin{array}{l}\oplus \oplus \oplus \ominus \\
\text { Moderate§ }\end{array}$ \\
\hline
\end{tabular}

${ }^{*}$ The two studies that contribute the most weight to this finding have high risk of bias. tThe risk ratio is too close to 1 and could easily include 1 if more trials are added. $¥$ Substantial heterogeneity of effect across studies.

$\S$ Only two to three studies have reported data on this outcome. IImprecise results with a wide $\mathrm{Cl}$. 
blockers (four studies) and renin-angiotensin system inhibitors (three studies). Ten studies enrolled both men and women and the rest enrolled only men. Six studies enrolled participants aged 65 years or younger and the others enrolled participants aged 18 to 70 years (one study), 40 to 79 years (one study), 45 to 75 years (one study), more than 50 years (one study), 55 to 80 years (one study), 60 to 79 years (study) and 65 to 74 years (one study).

Most studies were conducted in Western Europe and North America. Among the nine studies that provided data on race, the proportion of participants categorised as white was $0 \%$ (one study), $44 \%$ to $48 \%$ (two studies) and $86 \%$ to $100 \%$ (six studies). We adjudicated most studies to have a high risk of bias because of weaknesses in study design, conduct and data analysis.

Table 1 shows the summary of betablocker effects on key outcomes. When used as initial treatment for hypertension, there is low-certainty evidence that betablockers may reduce the risk of cardiovascular events compared with placebo. This beneficial effect is a reflection of the substantial reduction in strokes with beta-blockers since there is little or no difference in coronary events between patients on beta-blockers and those on placebo. There is moderate-certainty evidence that this effect of beta-blockers on cardiovascular events is similar to that of diuretics and renin-angiotensin system inhibitors, but it is inferior to that of calcium-channel blockers. In addition, there is moderate-certainty evidence that calcium-channel blockers and renin-angiotensin system inhibitors prevent strokes more than beta-blockers. However, there is moderate-certainty evidence that beta-blockers have little or no effect on all-cause mortality when used as initial treatment for hypertension. This effect of beta-blockers on mortality is identical to that of diuretics and renin-angiotensin system inhibitors, but it is inferior to that of calcium-channel blockers. Finally, there is low-certainty evidence that hypertensive patients on beta-blockers are more likely to discontinue medications due to adverse events than patients on renin-angiotensin system inhibitors. Nonetheless, there is little or no difference in adverse events between beta-blockers and diuretics or calcium-channel blockers.

Overall, treatment of hypertension leads to reductions in cardiovascular events with the degree of reduction dependent on the type of medication used to initiate treatment. Starting therapy with calcium-channel blockers or renin-angiotensin system inhibitors produces higher declines in cardiovascular events than with beta-blockers.

\section{LIMITATIONS}

All included studies added other antihypertensive medications to the initial therapy. Thus, it is possible that the suboptimal effects seen with first-line beta-blockers could have resulted from the additional medications used. Atenolol (a second-generation or selective beta-blocker) was the beta-blocker used in three-quarters of participants in beta-blocker arms. Thus, it is not possible to say whether the suboptimal effectiveness and safety seen with beta-blockers is a property of atenolol or is a class effect of all beta-blockers. We did not find any trials that assessed the effects of vasodilatory beta-blockers in preventing mortality or cardiovascular events. The certainty of the evidence for most outcomes was low, implying that the likelihood of further research finding the effect of betablockers to be substantially different from the results of this review is high.

Contributors All authors conceived and made substantial contributions to this editorial.

Competing interests None declared.
Provenance and peer review Commissioned; internally peer reviewed.

Data sharing statement Not applicable.

\section{(1) OPEN ACCESS}

Open Access This is an Open Access article distributed in accordance with the Creative Commons Attribution Non Commercial (CC BY-NC 4.0) license, which permits others to distribute, remix, adapt, build upon this work non-commercially, and license their derivative works on different terms, provided the original work is properly cited and the use is noncommercial. See: http://creativecommons.org/licenses/ by-nc/4.0/

(c) Article author(s) (or their employer(s) unless otherwise stated in the text of the article) 2018. All rights reserved. No commercial use is permitted unless otherwise expressly granted.

$$
\text { D Check for updates }
$$

To cite Wiysonge CS, Bradley HA, Volmink J, et al. Heart 2018;104:282-283.

Published Online First 29 July 2017

Heart 2018;104:282-283.

doi:10.1136/heartjnl-2017-311585

\section{REFERENCES}

1 Wiysonge CS, Volmink J, Opie LH. Beta-blockers and the treatment of hypertension: it is time to move on. Cardiovasc J Afr 2007;18:351-2.

2 Pucci G, Ranalli MG, Battista F, et al. Effects of $\beta$-blockers with and without vasodilating properties on central blood pressure: systematic review and meta-analysis of randomized trials in hypertension. Hypertension 2016;67:316-24

3 Smithwick RH. An evaluation of the surgical treatment of hypertension. Bull N Y Acad Med 1949;25:698-716.

4 Wiysonge CS, Bradley HA, Volmink J, et al. Betablockers for hypertension. Cochrane Database Syst Rev 2017:1:CD002003.

5 Bradley HA, Wiysonge CS, Volmink JA, et al. How strong is the evidence for use of beta-blockers as first-line therapy for hypertension? Systematic review and metaanalysis. J Hypertens 2006;24:2131-41.

6 Wiysonge CS, Bradley H, Mayosi BM, et al. Betablockers for hypertension. Cochrane Database Syst Rev 2007:CD002003.

7 Wiysonge CS, Bradley HA, Volmink J, et al. Beta-blockers for hypertension. Cochrane Database Syst Rev 2012. 